Volume: 7 Issue: 13 Year: 2021

\title{
Mazhar Bey’in Farkındalık Yolculuğu
}

Ayfer Şeyma ÜSTÜN

Marmara Üniversitesi

Yayıncılık Yönetimi

Yüksek Lisans Öğrencisi

ayferseyma@gmail.com

ORCID: 0000-0003-1600-5394

\section{Özet}

Mitolojik yapıya dayalı içeriklerin, okur ve izleyicinin ortak beğeni duygusuna hitap edebildiği bilinmektedir. Joseph Campbell bu durumu Kahramanın Yolculuğu paradigması üzerinden açılayarak metinleri; yola çıkış, erginlenme ve geri dönüş aşamaları üzerinden mitik kurgu çerçevesinde açıklamaktadır. Okuduğumuz, izlediğimiz ya da karşılaştığımız anlatıların hep "aynı" hikaye olduğunu, öne sürdüğü yolculuk kavramı çerçevesinde açıklamaktadır. Bu yolculuk, kahramanın fiziksel dönüşümü olabildiği gibi genellikle psikolojik temelleri olan bir erginlenme metaforunu da barındırmaktadır. Senaryosu ve yönetmenliğini Yavuz Turgul'un üstlendiği Yol Ayrımı filmi de Campbell'ın bahsettiği kahramanın erginleşme izleğini görebildiğimiz bir filmdir. Bu çalışmada Yol Ayrımı filminin Kahramanın Yolculuğu paradigması üzerinden okuması yapılacak, baş rol Mazhar Bey’in (Şener Şen) filmdeki dönüşümü üzerinden döngüye uyan ve bu döngüden ayrılan yönleri değerlendirilecektir. Nitel analiz tekniği kullanılarak gerçekleştirilecek araştırmada içerik analizi yöntemi kullanılacaktır.

Anahtar Kelimeler: Çağdaş Mitoloji, Joseph Campbell, Yavuz Turgul, Yol Ayrımı

\section{Mazhar Kozan's Journey of Awareness}

\begin{abstract}
It is known that content based on mythological structure can appeal to the common sense of taste of the reader and the audience. Joseph Campbell explains this situation through the Hero's Journey paradigm;
\end{abstract}


explains the mythic fiction through the stages of departure, initiation and return. He explains that the narratives we read, watch or encounter are always "the same" story, within the framework of the concept of journey he proposes. This journey can be the physical transformation of the hero, as well as an initiation metaphor, which usually has psychological foundations. The movie Yol Ayrımı, written and directed by Yavuz Turgul, is a movie where we can see the initiation of the hero Campbell mentioned. In this study, the movie Yol Ayrimı will be read through the Hero's Journey paradigm, and the aspects that fit and depart from the cycle will be evaluated through the transformation of the leading role Mazhar Bey (Şener Şen) in the movie. In the research, which will be carried out using the qualitative analysis technique, the content analysis of the relevant movie will be carried out by using the content analysis method.

Keywords: Contemporary Mytology, Joseph Campbell, Yavuz Turgul, Yol Ayrımı

\section{Giriş}

Joseph Campbell, Carl Gustav Jung’un psikanaliz çalışmalarında kullandığı arketip kavramını metinlere uyarlayarak anlatılara mitik bağlamda yaklaşmıştır. $\mathrm{Bu}$ anlamda kahramanın geçirdiği aşamaları üç ana bölüm ve toplam on iki alt başlıkta derlemiştir. Tüm bu süreçleri de Kahramanın Sonsuz Yolculuğu isimli çalışmasında açıklamıştır. Monomit kuramı olarak da adlandırılan bu paradigmada yola çıkış, erginlenme ve dönüş olmak üzere aşamalardan geçerek kahraman, erginleşerek ilk halinden çok daha farklı bir hale dönüşmektedir.

Christopher Vogler da Joseph Campbell'ın öne sürdüğü monomit kuramını Hollywood filmlerinden yola çıkarak senaryo ve öykü yazım tekniklerine uyarlamıştır. Kendisi de bu teknik üzerinden önde gelen birçok Hollywood film şirketine öykü danışmanlığı vermiştir. Yazarın Yolculuğu başlığı ile kaleme aldığı metninde Kahramanın Yolculuğunu Campbell'dan referansla açıklamaktadır. Bu kitapta, çağdaş anlamda mitolojinin imkanları gösterilmeye çalışılarak birçok filmin okuması bu paradigma üzerinden yapılmıştır. Vogler, bu çalışma ile yazarlığın mitolojik ve psikolojik kökenlerini açıklamaktadır.

Senaryo yazımını ve yönetmenliğini Yavuz Turgul'un yaptı̆̆ı Yol Ayrımı filmini de Kahramanın Yolculuğu paradigması üzerinden okumak mümkündür. Her ne kadar olay örgüsü ve zaman, lineer bir düzlemde ilerlemese de Vogler'1n bahsettiği on iki basamağı bu film üzerinden izlenebilmektedir. Nitekim çağdaş bir senaryoya sahip olmasına rağmen ana olay örgüsü ve basamakların mitik yapıya dayalı olduğu görülebilmektedir. Bu metinde de baş karakter Mazhar 
Bey'in fizikselin ötesinde psikolojik erginlenme ve inisiyasyon şeması ilgili basamaklar üzerinden açıklanmaya çalışllacaktır. Nitel araştırma yöntemi ve içerik analizi üzerinden filmin okuması Kahramanın Yolculuğu paradigması üzerinden yapılacaktır. Nitekim bu filmde Mazhar Bey'in katı kalpli ve donuk hayatından, sevecen ve güler yüzlü bir adama dönüşme adımları da bu izlek üzerinden gösterilmeye çalışllacaktır. Mazhar Bey'in davranışlarının ve dönüşümünün tutarlı olup olmadığı da yine bu izlek üzerinden tartışlacaktır.

\section{Kahramanın Yolculuğu}

İnsan farklı yerlerde bulunsa, gittiği yerler değişse, konuştukları farklılaşsa da kaynaktaki düşüncenin kültürel zemin ile bağlantılı olduğu bilinmektedir (Özmen, 2018: 29). Mitler kadim anlatı formları ile insanlık tarihi kadar eski hikayeler ve inançlar hakkında günümüze 1şık tutmakta, yol gösterebilmektedir. Bu anlamda mitik anlatıyı dinamik bir form üzerinden okumak önemlidir (Bayat, 2007: 12). Böylelikle günümüz insanının yaşadığı modernizme psikolojik çıkmazların kökeni de bu hikaye temelleri üzerinden yorumlanabilmekte, algı seviyesine farklı bakış açılarını getirmeyi mümkün kılabilmektedir (Campbell ve Moyers, 2021: 24).

$\mathrm{Bu}$ anlamda Joseph Campbell'ın Kahramanın Sonsuz Yolculuğu çalışmasında öne sürdüğü aşamaları kısaca tanımak faydalı olacaktır. Campbell bu eserinde şekil değişse de hep aynı biçimde tekrarlayan anlatı dizgelerine mitolojik kodlarla yaklaşır ve üç ana toplamda ise on iki alt başlıkta tüm anlatı biçimlerini özetlemektedir (Campbell, 2010). Yola çıkış olarak da isimlendirilen birinci bölümde metne dair sıradan dünya tanıtılarak kahramanın günlük hayatı okura/izleyiciye gösterilmektedir. Kahramanın günlük hayatı tanıtıldıktan sonra kahraman, bir maceraya çağrı alarak herhangi bir konu üzerinde değişim yaşaması ya da bir görev gerçekleştirmesi konularında teşvik edilmektedir. Ancak kahraman bu çağrıyı reddederek konfor alanından çıkmayı reddeder ve gündelik hayatındaki döngüsüne devam etme konusunda ısrarcı olur. Bu noktada akıl hocası figürü ile bir rehber belirerek kahramanı yolculuğa çıkma konusunda ikna eder ve ona destek olacağını da bildirir. Böylelikle ilk eşik aşılmış olunur (Campbell, 2010).

İlk eşiği aşan kahraman, sıradan dünyadan özel olan alana doğru geçmeye başlayarak burada onun değişimi ile alakalı büyük sınavı vereceği alana doğru yaklaşır. İkinci bölüm olarak da bilinen bu yolda birçok sınavlar ile karşılaşılır, dostlar ve düşmanlar edinilir. Gerçekleştirilmesi gereken hedef doğrultusunda ilerlerlenirken kahraman, korkuları ile yüzleşme sürecine doğru da adım adım 
yaklaşır. Kahramanın gerçekleştirdiği yüzleşme ne kadar onun farkındalığı ile alakalıysa o derece etkili bir hikayeye tanık olunabilmektedir (Vogler, 2020: 153). Kahraman bu aşamada bir çok rakibi alt eder, ancak büyük çilesini gerçekleştirerek gerçek anlamda "kahraman" olabilmektedir (Vogler, 2020: 223).

$\mathrm{Bu}$ çile gerçekleştirildikten, büyük yüzleşme yaşandıktan sonra ise üçüncü bölüme geçiş yapılır; kahraman ödüllendirilir. Bu ödül ile kahramana daha önce sahip olmadığı bir güç, farkındalık ya da enerji gibi bir bağış verilmektedir. Kahraman artık dönüş yoluna geçerek burada yeniden dirilir ve yaşadığı farkındalığı perçinleyerek adeta yeni bir iksirle dönmektedir. Tüm bu aşamalar sonsuza kadar dairesel bir döngü halinde devam ederek kahramanın sonsuz anlamdaki yolculuğunu mümkün k1lmaktadır (Campbell, 2010).

\section{Yol Ayrımı Filmi Hakkında}

Senaryo yazarlığı ve yönetmenliğini Yavuz Turgul'un yaptığı Yol Ayrımı filminin konusu, hayatını babasından devraldığı tekstil şirketini büyütmeye adayan Mazhar Kozanlı (Şener Şen)'nın hayatı üzerinedir. Mazhar Kozanlı'nın agresif ve acımasız yöntemlerle bunu gerçekleştirdiği görülmekle beraber yaşadığı trafik kazası neticesinde kazandığı farkındalık da filmin kilit noktasını oluşturmaktadır. Nitekim bu durum Mazhar Kozan'ı, yaptığı tercihin bedelini ödemek ya da pes etmekle karşı karşıya kalmasına sebep olmaktadır.

Varlıklı bir ailenin şirketini yöneten Mazhar Kozanlı'nın toplumsal anlamda duyarlı biri olmasının aşamalarını izleyebildiğimiz filmde oyuncu kadrosu; Şener Şen, Rutkay Aziz, Mert Fırat, Nihal Yalçın, Çiğdem Selışık Onat, Tilbe Saran, Ruhsar Öcal, Defne Kayalar, Şerif Erol v.d. isimlerden oluşmaktadır. Film müziklerini Anjelika Akbar'ın yaptığı filmin yapıncılığını ise Erol Avcı üstlenmiştir.

\section{Yöntem}

\section{Amaç}

Araştırmanın amacı, Yol Ayrımı filmini Kahramanın Yolculuğu paradigması üzerinden okuyarak olay örgüsünün yapılandırılma biçimine farklı bir bakış açısı kazandırmaktır. Mitolojinin çağdaş 
anlamda dönüştürüldüğg̈ne sıklıkla tanık olunan sinema sektöründe, Yol Ayrımı filminin ne derece bu kurguya dahil olabildiği sorgulanmaya ve tespit edilmeye çalışılacaktır. Bu anlamda aşağıdaki soru çerçevesinde film tahlil edilecektir:

1. Yol Ayrımı filmi Kahramanın Yolculuğu paradigmasına uygun bir yapıda mıdır?

2. Bu yapıya uygun bir filmse yolculuk aşamaları tutarlı olarak kullanılmış mıdır?

\section{Araştırmanın Önemi}

Araştırma, dönüşüm izleklerinin görülebildiği Yol Ayrımı filminde, mitolojik anlatının hangi biçimlerde kullanıldığının tespit edilebilmesi adına önemlidir.

\section{Yöntem}

Araştırma nitel temellidir, Kahramanın Yolculuğu paradigması üzerinden film çözümlemesi gerçekleştirilecektir. Bu anlamda içerik analizi yöntemi kullanılacaktır.

\section{Mazhar Beyin Farkındalık Yolculuğu}

\section{Birinci Bölüm}

\section{Gündelik Dünya}

Film, Mazhar Kozan'ın yılın iş adamı seçilmesi ile alakalı konuşması ile başlar. Mazhar Bey, Normalde hastanede olmasına rağmen konuşması için hastaneden çıktığını ifade eder, gülümseyen çehresi ile izleyicilere bakmaktadır. Aslında Mazhar, varlıklı bir ailenin katı kalpli bir bireyidir. Bu sahnedeki gülen yüzü, filmin sonundaki değişimin derecesi hakkında izleyiciyi tetiklemektedir. Nitekim Mazhar empati yoksunu, insan ilişkileri yok denecek kadar az, hiç aşık olmamış, doğru düzgün gülmemiş bir kişi olarak gösterilmektedir. Annesi, oğlu ve babası ile yaşadığı çatışmaları da görülebilmektedir. 
Gündelik dünyada örnek olarak oğlu Barlas ile ilişkisi verilebilir. Oğlunu aile şirketlerinde küçük bir çocuk gibi azarlayabilen Mazhar Bey'in alkolik oğluna karşı hiçbir toleransı yoktur. Barlas babasına stresten içtiğini söylese de Mazhar Bey empati yoluna gitmez, tekrarı halinde işleri ayıracaklarını ifade eder. Özetle, Mazhar Bey'in, ailesi ile düzgün bir ilişkisi yoktur. Onun gündelik hayatı adeta ruhsuz ve buz gibi bir adam üzerinden görülmektedir. Oldukça varlıklı olan ailesinin Mazhar Bey’e karşı son derece saygılı olduğu ise dikkat çekmektedir.

\section{Maceraya Çağrı}

İşten atılmış işçiler, Mazhar Bey şirketten çıkarken kendisine slogan atarak tepki gösterir. Bir işçi makineyi parçalamış olsa da Mazhar'ın yardımcısı Besim, kendisine bunun önemsiz olduğunu ifade eder. Mazhar bey kendi aklına gelen yöntemi ile makineyi kıran kadınla karşılaşıp görüşmeyi ve etkisiz hale getirmeyi doğru bulur ve şöförsüz olarak arabayı kullanır. Burada işçilerle görüşme ve onları dinlemeye yönelik bir maceraya çağrı alınmaktadır.

\section{Çağrının Reddi}

Mazhar Bey ise işçi kadın ile (Emine) göz göze gelmesine rağmen ona tepki vermez. Kadın kendisine çok ağır cümleler kullanır ve beddualar eder. Mazhar Bey ise bunların hiçbirinden etkilenmez. Çağnyı reddederek hissiz bir şekilde satın almak istediği farklı bir şirketin patronu ile yemeğe geçer. $\mathrm{Bu}$ kısımda Campbell'in de bahsettiği konfor alanından çıkışın reddi görülebilmektedir.

\section{Rehberle Karşılaşma}

Mitolojik kaynaklarda bilge bir rehberin yol göstericiliğine tanık olunurken bu filmde bir iş yemeği üzerinden mentor karakter görülebilmektedir. Yemek yediği iş adamı bir akıl hocası biçiminde Mazhar Bey'in hatalı davranışlarını ifade eder. Kendisine; ahlaksızlık yaptığını, ve doğru bir değer 
yargıya sahip olmadığını da ekler. Mazhar Bey ise bu akıl hocasını umursamaz. Mazhar, muhatabının şirketini işten çıkarmalar yoluyla almakta ısrarcıdır. Bu anlamda çağrıyı reddettiğini, akıl hocasını da dinlemediği izlenmektedir.

\section{İlk Eşiği Geçiş}

Yemekten sonra dönüş yolunda giderken Mazhar Bey trafik kazası geçirir ve zorunlu bir eşikten geçiş süreci yaşar. Hastanede büyük müdahalelerden sonra hayata döner. İlk eşiği geçtiğinin en önemli ibaresi de Mazhar Bey'in kendisine çarpan kişiye ne olduğunu sormasıdır. Nitekim daha önce bunu çok umursamayan bir mizaca sahip olduğu görülmekteydi. Mazhar Bey ailesi yanında, rehabilite olmaya çalışır. Evinin bahçesinde yalnız şekilde yürüyüp iyileşmeye çalışırken yağmura gülümsemesi de bu yeni ve özel dünyaya girişin bir başka metaforu olarak görülmektedir. Mazhar Bey'in aynaya bakarak öz benliği ile sembolik karşılaşması, kendine yarım da olsa tebessüm etmesi bir diğer özel dünya metaforu olarak okunabilmektedir.

Çok istediği o akıl hocasının sahibi olduğu şirketi alacak olmalarına dair haberi, doğaya ve çevresine yönelik farkındalıkla yanıtlaması da Mazhar beyin bir diğer özel dünya dair farkındalığına dair ip uçlarını sunmaktadır. Ayrıca bu şirketi satın almaya dair eski hevesi bulunmamakta, "düşünelim” demekte, adeta empati kurmaya başlamaktadır. Özel dünya olarak adlandırılan hastaneden sonraki döneminde Mazhar Bey'in, etrafina karşı daha duyarlı, sosyal ve güler yüzlü olduğu görülmektedir. "Önemli olan sağlık” gibi insani ilişkiler kurması da Mazhar beyin kendisi ve çevresi ile dost olmaya başlamasının göstergeleridir. Tüm bu dönüşümün ise çok ani şekilde gerçekleştĭgini, seyircinin yeteri kadar ikna edilmeden geliştĭgi de dikkat çekmektedir.

\section{İkinci Bölüm}

\section{Sınavlar-Müttefikler-Düşmanlar}

$\mathrm{Bu}$ bölüm, özel dünyadaki kahramanın yolculuğu bakımından engellerin aşılıp kahramanın korkuları ile yüzleşmeye hazırlayan aşama olması bakımından önemlidir. Nitekim Mazhar Bey, 
özel dünyaya girdikten sonra eski çevresindeki kişileri "düşman” olarak algilamaya, önceden farkında olmadıklarını ya da düşman olduklarını da "dost" gibi görmeye başlar. Örneğin, hayat arkadaşı olan karısını terk eder, ve evliliklerinin zaten bir proje olduğunu daha fazla devam etmemesi gerektiğini söyler. Mazhar Bey, bu yeni döneminde artık hayatı dolu dolu yaşamayı, insanı ve farkındalıkları merkeze koymayı en önemlisi de özgür ve "kendi gibi olmayı" hedeflemiştir. Mazhar bey, her şeyi yeniden gözden geçirmenin zamanı geldiğini ifade ederek karısına yola çıkar.

$\mathrm{Bu}$ sebeple de karısını terk ettikten sonra arkadaşı Altan'ın kapısını çalar ama arkadaşı onu gördüğüne memnun olmaz, kapıyı kapatır. Galatasaray Lisesi’nden sınıf arkadaşı olan Altan ile aslıda zıt iki kutup gibilerdir. Altan da kendisine siyah ve beyaz kadar farklı olduklarını ifade eder. Bu zıtlık anlatıdaki Mazhar beyi ve psikolojik derinliğini daha iyi tanımamıza hizmet etmektedir. Nitekim her şey zıddı ile kaimdir. Altan'ın evinde misafir olarak kalan Mazhar Bey, tekrar kendisi ile arkadaş olur. Artık değiştiğini bu arkadaşına davranışları ile de ifade eder.

İşçi sınıfına karşı kazandığı farkındalık, Mazhar Bey'in çalışanlarına karşı daha empatik yaklaşmasına sebep olmuştur. Bu sebeple Mazhar bey tüm hissedarları toplar ve karar ve söz hakkının sadece kendisine ait olduğunu hatırlatır. Kendi \%60 hissesini çalışanlarına pay ederek hissedar yapacağını, mirasından ailesinin kimsenin pay alamayacağını ifade eder. Çalışan annelerin çocukları için kreş, yurt dışı üniversiteler için öğrencilere burs, ve yönetimi aile ile beraber çalışanların temsilcilerinden oluşan bir kurulun temsil edeceğini de ekler. Annesi ise bu kararlara yüksek sesle karşı çıkar. Onun tepkisine Mazhar bey tebessüm ederek karşılık verir. Satın almak için işçileri çıkarması gerektiği şirketi almaktan vaz geçtiğini söyler. Oğluna da önemli bir idarecilik konumu da verir. Gündelik dünyada Mazhar Bey'in annesi ile olan çatışması ego temelli iken özel dünyada bu çatışma seviyesinin statükoya karşı direnç ya da değişim temeli üzerinden ilerlemektedir.

Mazhar Bey'in aldığı kararların üstüne, öz annesi Firdevs Hanım, mahkemeye başvurarak hacir talebinde bulunmayı teklif eder (akıl sağlığını kaybettiğine dair rapor). Bu rapora dair görüşüldüğü esnada, Mazhar Bey arabanın çarptığı köpeği veterinere götürerek tedavi ettirmektedir. Aslında insani yönü ortaya çıkan Mazhar Bey, şirket ve ailesi tarafından deli damgasını yemektedir. Oğlu ise bu anlamda babasını ikna etme durumuna gidilmesi gerektiğini söyler. Eskiden rakip ya da düşman gibi gördüğü babasına yardımcı olma yoluna gider. Mazhar Bey’in müttefiki rolüne geçer. 
Ardından kızı, oğlu ve annesi Mazhar Beyle görüşür. Sıradan dünyada kendisi ile ilgilenmediklerini, şimdi de böyle bir değişimi makul karşılayamacaklarını ifade ederler. Miras hakkından vazgeçmek istemediklerini, Mazhar Beyin kendileri için sadece güç ve paradan ibaret olduğunu söylerler. Hayallerini çaldığını, kurumuş bir ağaç gibiyken birden dönüşerek çılgınca kararlar aldığından yakınırlar. Ailenin birbirine bağlandığı unsurun ancak şirket olduğunu ve bunu da yıktığını Mazhar Beye ifade ederler. Bu anlamda gündelik hayattaki dost olan figürlerin özel dünyada düşmana dönmesi makul görünmektedir. Nitekim Mazhar Bey’in dönüşümüne dair temellendirme yeteri kadar yapılmadığı için muhataplarının serzenişleri izleyici tarafından haklı olarak görülmektedir. Mazhar bey, geçtiği eşikteki farkındalığını ailesine söylese de izleyici yeteri kadar görsel ve içeriksel bağlamda ikna edilmediği için konuşmalar havada kalmaktadır. Kararından vazgeçmeyeceğini yineleyerek ifade ettiğinde ailesindeki tüm bireyler de Firdevs hanımın cephesine katılmış olur.

\section{Mağaranın Derinliklerine Yaklaşmak}

Kendisine beddua eden ve arabanın önüne atan işçi kadının görüntüsü, tansiyonun tırmanacağına dair haberci niteliğindedir. Kadının ölümcül hastalığa sahip oğlunun yanına gitmesi de hikayeyi beslemekte ve aksiyona dair tırmanışı arttırmaktadır. Ardından işçi kadın ve Mazhar Bey’in civarında gerçekleşen silahlı eylem gösterisi, Emine'nin mağaranın derinliklerine dair ip ucu niteliğindedir. Ancak bunun, Mazhar Bey’in değil, Emine'nin mağaranın derinlikleri metaforu ile alakalı bir ayrıntı olması, hikayesini izlediğimiz, dönüşümünü takip ettiğimiz Mazhar Bey’in erginlenme süreci ile alakalı olarak bir kopukluğa sebep olmaktadır.

Emine'nin Mazhar Bey ile yakın olarak gösterilmesi, Emine'yi yakın zamanda en büyük korkusu ile yüzleşmeye hazırlamaktadır. Kadının bir gecekonduda yaşadığını ve maddi olarak gerçekten zor şartlarda olduklarını gören Mazhar bey, bu kadın ile bir empati kurmaktadır. Nitekim mutfakta ağlayan kadın, onu da duygulandırmıştır. İşçi kadın, arabanın önüne atlayan ve beddua eden Emine ile onu Nur'un Gemisi'nde karşılaşır ve yine Mazhar'a hakaret eder. Mazhar bey, Emine’ye karş1 anlayışlı bir tepki vererek yatışmasını bekler. Ancak daha önce de ifade edildiği gibi bu, Mazhar'ın değil Emine’nin yolculuğunun merkezi ile alakalıdır. 


\section{Çile}

Mazhar, trafik kazasında fazla hızlı ve yakıcı bir uyanış yaşadığını, boş şeyler için parçalanan bedenlerini gördügünü söyler. Mazhar'ın en karanlık yanı ile yüzleştiği ve farkındalık kazandığı kaza anı, izleyiciye gösterilmeden sözel olarak ifade edilmiştir. Adeta hikayenin en can alıcı kısmı olan Çile, geçiştirilmiştir. Nitekim Mazhar Bey bu bölüm sayesinde herkesin pencerelerinin birbirine kapalı olduğunu, artık bunları açmaya çalıştığını söyler. Barlas’a boşuna alkolik olmadığını, kendisine yaptığı baskılar yüzünden bu şekilde içtiğini de ifade eder. Ölümle burun buruna gelmesi Mazhar Bey’in çilesidir. Ancak yeterli olgunlukta ifade edilmediği için eşiğin aşılması izleyiciye tam anlamı ile geçememekte, Mazhar Beyin davranışlarına hak verme konusunda zorlanılmasına sebep olmaktadır. Sadece Mazhar Bey’in konuşmaları ile verilen Çile, gösterilmemektedir. Bu yüzden Mazhar Bey’in yüzleşmeleri de yüzeysel olarak izleyiciye geçmektedir.

Farklı şekillerde ifade edilen Mazhar Bey'in Çilesi, hakimle konuşurken daha ayrıntılı olarak verilmektedir. Ölüm halini, nasıl tecrübe ettiği aktarılmaktadır. Çilenin yani ölüm halinin, yaşa dığı hayattan pişmanlığı ve yaşadığı gördüğü hislerin onu yaktığını, cehennemi gördüğünü ifade etmektedir. Kendisine ikinci bir şans dilediğini söyler. Burada cehennem, Campbell'in de bahsettiği ateşten gömlek evresidir. Ancak yeterli ön koşullar üzerinden verilmemesi ve işlenmemesi, Mazhar'ın dönüşümüne dair seyircinin ikna olmasını zorlaştırmaktadır.

\section{Üçüncü Bölüm}

\section{Ödül}

Mazhar beyin çektiği çile, onun etrafına karşı farkındalık kazanması bağlamında bir ödül ile taçlandırılmıştır. Mazhar bey, eskisi gibi değildir ve bu insani yönü kuvvetli olan bir karakter olması dolayısıyla önemlidir. Mazhar Bey’in önemli ödülü de işte bu toplumsal farkındalık ve insani yandir. 


\section{Dönüş Yolu}

Dönüş yoluna Emine ile konuşması ile girmeye başladığı söylenebilir. Kendisine muhtaç olan ama bunu kabul etmek istemeyen Emine'nin konuşmasına, Mazhar Bey kendisinin Emine'nin merhametine ihtiyacı olduğunu söyleyerek ifade etmektedir. Böylelikle Emine kendisini dinler, bu avantajlı teklif Emine'yi yumuşatmıştır. Dönüş yolundaki Mazhar bey, aldığı kararları uygulama yolunda ilerlemektedir. Ancak Dönüş Yolundan Gündelik Hayata doğru geçerken geçilen eşikte, Mazhar Bey'i birtakım engeller beklemektedir. En temel engel de annesi Firdevs Hanımın arkasından çevirdiği işlerdir. Bu mahkeme işleri ile alakalı olarak gönlünü aldığı oğlu Barlasla karşı karşıya gelmek zorunda kalması da bir diğer çatışma olarak karşımıza çıkmaktadır.

Besim yani yardımcısı, noter yanında imzalanması gereken bir belgeden bahseder. Bu konuşma Firdevs Hanımın kendisini ikna etmesi neticesinde gerçekleşebilmiştir. Arkadaşı Altan ile içki içip sarhoş olmanın eşiğinde olan Mazhar Bey kendisine Fransızca "bana ihanet etme” demiştir. Besim de "mümkün mü" diye sorarak tansiyon ve gerilimi yükselten bir ifadeye filmi kavuşturmuştur. Tüm bu ifadeler, dönüş yolundaki Mazhar Bey’in hikayesindeki gerilimi tırmandırmayı sağlamaktadır.

Şirkete taksi ile gelen Mazhar Bey, Besim ile karşılaşır. Siyah bir minibüsten birsürü adamın indiğini görür. Besim kendisine, sulh hukuk hakimi ile görüşmesi gerektiğini ifade eder. Mazhar, çaresizce kabul eder. Yardımcısının kendisine ihanet ettiğini ifade etse de yardımcısı, aklın yolunu seçtiğini söyler. Hukuk hakimi de kendisini ikna etmeye çalışır. Akıl sağlığı ile alakalı olarak raporlar alınacağını, tabiri caizse hayatının eskisi gibi olamayacağını ifade eder. İkna olması durumunda bunlara gerek olmadığını söyler.

Yaşadığı çileyi ve ateşten gömleği, ölüm kalım durumunu hakime anlatan Mazhar bey, caymadığını söyler. Artık tüm mal varlığına tedbir konması, hastanede tetkik yapılması vb. konular üzerinden hacir kararı çıkarılacaktır. Eminenin cafesindeki Nur, bir avukat olarak ona bu evrede akıl hocası rolüyle yol göstermekte, savaşması ya da kabullenmesine dair Mazhar Beye karşılaşabilecekleri hakkında bilgilendirmektedir. 
Firdevs Hanım Besim'i, Mazhar beyin tüm harcamalarından sorumlu olduğunu ifade eder. Bu da Mazhar Beyin diriliş evresine geçmesinde bir başka engeldir. Mazhar, Besim'in evine giderek onu ikna etmeye çalışır. Statükonun korunmasına yönelik Besim kendi duygularını ifade etmektedir. Israr etmemesi gerektiğini, yoksa annesinin istediğinin olacağını söyler. Mazhar ise Emine ile alakalı çocuğunun masraflarının karşılanması ve işçi haklarının savunulması gerektiğini Besim'e ifade eder. Mazhar Bey artık işçilerin ve çevresinin sorumluluklarını omuzlarında hissederek gündelik hayatındaki hatalarını telafi etme yoluna gider. Bu telafi, kendi ailesinde ise evlatlarına karşı güler üz ve torunu ile alaka olarak görülmektedir.

\section{Diriliş}

Mazhar Bey adeta Nur'un Gemisi'nde dirilmeye başlar. Kafenin adının da mitolojik/dini kaynaklı bir hikayeye dayanması da dikkat çekmektedir. Mazhar Bey, burada arkadaşları ile oturmakta ve dertleşmektedirler. Öyle ki Mazhar Bey burada, aslında karşı olduğu ve tepki gösterdiği bisiklete binmeye bile başlar. Bisikletin önemi Mazhar bey için, küçüklüğünde babasının parçaladığı bir eşyası olduğu için travmaya sebep olduğu da sonradan anlaşılacaktır. Bu travmasını Nur'un Gemisi'nde aşması önemli bir diriliş metaforudur.

Mazhar Bey, işçi Emine ile dostça konuşur. Altan'ın hastaneye kaldırılmasıyla gidecek yeri de kalmayan Mazhar bey, Emine'nin evine giderek orada kalır. Arkadaşı altan, ölüm eşiğinde kendisine anı yaşamasına dair son sözlerini söyler ve ölür. Ölen arkadaşının iyi bir hayat yaşadığı için iyilerin karşılayacağını söyler ve annesine seni kim karşılayacak diye sorar. Mazhar da arkadaşını dinler ve şiirler okumaya başlar ve hastaneye gitmeyi kabul eder. Dirilişi, etrafina sağladığı pozitif etkiler üzerinden izlenebilmektedir.

\section{İksirle Dönüş̧}

Emine'nin işine kavuşması ve yüzünün gülmesi Mazhar'ın en önemli iksirlerinden biridir. Annesinin hastaneye gelerek Mazhar'a filmin başında ifade edilen yılın iş adamı ödülü ile alakalı törene katılma teklifini eder. Mazhar adeta son bir farkındalıkla şirkete dönüş yaşamakta, anlatı 
dairesel olarak başladığı yere varma imkanı bulmaktadır. Törene gitme ya da gitmemeye dayalı bir arada kalmışlık yaşayan Mazhar, ödül törenine, başta da gördüğümüz üzere gider. Bu geri dönüş ve yaşadığı farkındalık perçinlenerek izleyiciye sunulur.

\section{Bulgular}

\begin{tabular}{|c|c|}
\hline Gündelik Dünya & $\begin{array}{l}\text { Mazhar Kozanlı Galatasaray Lisesi'nden } \\
\text { mezun, anne ve babası ile yaşadığı çatışmalar } \\
\text { onu ego temelli birey haline getirmiştir. Bir } \\
\text { aile şirketi olan Tekstil şirketleri } \\
\text { bulunmaktadır. Söz yetkisi kendisine aittir. } \\
\text { Katı kalpli, sert mizaçlı, empati yoksunu, hiç } \\
\text { gülümsemeyen, soğuk bir kişidir. İnsan, doğa, } \\
\text { hayvan fark etmeksizin canlı-cansız hiçbir } \\
\text { şeye karşı sevgi beslememektedir. }\end{array}$ \\
\hline Maceraya Çağrı & $\begin{array}{l}\text { Mazhar Bey, ayaklanan işçilerin protestoları } \\
\text { ile maceraya çağrı alır ve tek başına onların } \\
\text { karşısına araba ile çıkmaya karar verir. }\end{array}$ \\
\hline Çağrının Reddi & $\begin{array}{l}\text { Emine'nin kendisini Mazhar Bey'in arabasının } \\
\text { önüne atması ve kendisine beddua ve } \\
\text { hakaretler savurmasına Mazhar Bey hiçbir } \\
\text { tepki vermez. }\end{array}$ \\
\hline Akıl Hocası İle Tanışma & $\begin{array}{l}\text { Satın almak istediği şirketin patronu ile iş } \\
\text { yemeği yer ve kendisine akıl hocası şeklinde } \\
\text { akıl verir. Merhamet ve insanlıktan bahseder. } \\
\text { Ancak Mazhar onu dinlemez. }\end{array}$ \\
\hline İlk Eşiği Aşma & $\begin{array}{l}\text { Mazhar Bey geçirdiği trafik kazası ile eşiği } \\
\text { zorunlu olarak aşmaktadır. }\end{array}$ \\
\hline Sınavlar-Müttefikler-Düşmanlar & $\begin{array}{l}\text { Günlük hayatında kendisine saygılı davranan } \\
\text { ailesi Mazhar Bey’e karşı cephe alarak } \\
\text { düşmanı hükmüne girer. Eski dostu Altan ile }\end{array}$ \\
\hline
\end{tabular}




\begin{tabular}{|c|c|}
\hline & $\begin{array}{l}\text { yeniden görüşmeye başlar ve önceden düşmanı } \\
\text { hükmünde olan işçi ve alt sınıf insanlar da } \\
\text { dostları olmaya başlar. }\end{array}$ \\
\hline Mağaranın Derinliklerine Doğru & $\begin{array}{l}\text { Trafik kazası ani olarak verilmiştir, mağaranın } \\
\text { derinlikleri çok hızlı geçilmiştir. }\end{array}$ \\
\hline Çile & $\begin{array}{l}\text { Mazhar Bey’in trafik kazasında yüzleştiği } \\
\text { ölüm-kalım durumu ve dönüşümü kahramanın } \\
\text { kendi dilinden verilmiş olup seyirciye } \\
\text { gösterilmemiştir. Mazhar Bey’in dönüşüm } \\
\text { temelleri yeterli olgunlukta ifade edilmemiştir. }\end{array}$ \\
\hline Ödül & $\begin{array}{l}\text { Mazhar’ın en önemli ödülü kazanın ardından } \\
\text { kazandığı insani yön ve farkındalıktır. }\end{array}$ \\
\hline Dönüş Yolu & $\begin{array}{l}\text { Mazhar Bey’in kazandığı farkındalıkla beraber } \\
\text { gündelik hayatına geçişinde hatalarını telafi } \\
\text { etmesi ve karşılaştığı engeller dönüş yolunu } \\
\text { ifade etmektedir. }\end{array}$ \\
\hline Diriliş & $\begin{array}{l}\text { Mazhar Bey adeta Nur'un Gemisi’nde } \\
\text { dirilmeye başlar. Burada arkadaşları ile adeta } \\
\text { yeni bir hayata ve imkansız olarak göreceği } \\
\text { tarzda içtenliğe kavuşmaktadır. }\end{array}$ \\
\hline İksirle Dönüş & $\begin{array}{l}\text { Emine' nin işine kavuşması ve yüzünün } \\
\text { gülmesi Mazhar'ın en önemli iksirlerinden } \\
\text { biridir. Hastanede Firdevs Hanımın kendisini } \\
\text { ödül törenine daveti ve Mazhar Bey’in buraya } \\
\text { katılarak gerçekleştirdiği konuşma, iksirle } \\
\text { dönüş evresini işaret etmektedir. }\end{array}$ \\
\hline
\end{tabular}

Tablo1. Mazhar Beyin Yolculuk Şeması 


\begin{tabular}{|l|l|}
\hline Mağaranın Derinliklerine Doğru & $\begin{array}{l}\text { Bu kısım, Emine'nin temel korkusu üzerinden } \\
\text { işlenmiştir. Patronu ile yüzleşeceği sahneye } \\
\text { doğru aksiyon tırmandırılmıştır. }\end{array}$ \\
\hline Çile & $\begin{array}{l}\text { Çile kısmı da Emine karakteri üzerinden } \\
\text { izleyiciye gösterilmektedir. Mazharın Çilesi } \\
\text { izleyiciye sadece kelimeler üzerinden sözel } \\
\text { ifadelerle aktarılmaktadır. Emine ve Mazhar } \\
\text { yüzleştirilerek Emine'nin temel korkuları ile } \\
\text { barışması sağlanır. Emine Artık Mazhar’ı } \\
\text { düşman olarak görmeyi bırakır. }\end{array}$ \\
\hline
\end{tabular}

Tablo2. Mazhar Beyin Yolculuğunda Aksayan Yönler

\section{Yol Ayrımı Filminde Mazhar'ın Çatışma Seviyeleri}

Mazhar Bey’in oğlu Barlas ile yaşadığı çatışma, gündelik hayattaki karakteri hakkında fikir vermektedir. Gündelik hayatta otoriteyi temsil eden Mazhar Bey’in bu tutumu ise benzer şekilde kendi otoriter babası ile olan ilişkisi ile temellendirilmektedir. Benzer şekilde kızı Defne olan iletişiminin babası tarafından sevilmemiş olan kızın duyguları üzerinden aktarılması da anlatıyı zenginleştirmektedir. Mazhar beyin toplumsal çatışmasının merkezi ise işçi sınıfı üzerinden verilmektedir. Kahraman, çevresi ile duyarlı bir hale gelip barışarak bu çatışmayı sükunete kavuşturmuştur.

Mazhar Bey’in annesi ile olan çatışması da hikayede önemli bir yere sahiptir. Babası zamanında kocasının sırtını dayadığı, şirket işlerine karışan kadın figürü olan Firdevs Hanım ile Mazhar Bey’in çatışması gerek gündelik gerekse özel dünyada devam eden bir forma sahiptir. Ancak gündelik dünyadaki çatışma salt egosal temellere dayanırken özel dünyadaki çatışma egonun ötesinde statükoya karşı bi başkaldırı niteliğindedir. Her başarının kendi sayesinde olduğunu düşünen Firdevs hanım aile şirketinin devamı ve statükoyu temsil etmektedir. Şirketin devamı için Mazhar'ın aldığı karardan döndürebilmek için oğluna deli raporu almaya çalışırken bir yandan 
aslında kendi akıl sağlığının yerinde olmadığını, kendi kendine konuşma sahneleri üzerinden görülebilmektedir.

\section{Sonuç}

Yol Ayrımı filminde baş kahraman Mazhar'ın kendisini, yaşadığı farkındalık üzerinden feda etmesini izlemekteyiz. Kahramanın kahraman olabilmesi için gerçekleştirilen fedakarlık, bu filmde Mazhar Bey'in yaşadığı farkındalık üzerinden, toplumsal (işçi sınıfı üzerinden) bir bağlamla sunulmaktadır. Bu yolculukta Mazhar Bey'in gündelik dünyadan özel dünyaya geçişinin son derece ani olarak verilmesi, karakterin hareketlerinin tutarlılığı bağlamında seyirciyi zorladığ tespit edilmiştir. Bu yüzden farklı karakter ya da figürlerle diyalogları üzerinden Mazhar Bey'in sürekli ölüm kalım durumu ile karşılaştığı için toplumsal farkındalık kazandığını ifade ettiği görülmektedir. $\mathrm{Bu}$ anlamda mağaranın derinlikleri ve çile bölümleri daha iyi çalışılarak ifade edilseydi, Mazhar Bey'in yaşadığı o trafik kazası ve ölüm kalım durumu sürekli ssıtılarak seyircinin önüne konmak zorunda kalınmayacağını söylemek mümkündür.

Filmde mağaranın derinlikleri ile alakalı içerikler kurgusal olarak filmi beslemekle beraber Mazhar Bey'in temel çilesini aktarmamaktadır. Nitekim burada Mazhar'ın değil, Emine'nin çilesine giden yol ayrıntılı olarak işlenmektedir. Film, Mazhar Bey'in Çileye yaklaşım süreci ve psikolojisini aktaramamıştır. Nitekim Mazhar beyin mağaranın derinliklere girişinin yaşadığı farkındalıktan önce olması beklenmektedir. Bu durum da ani bir trafik kazası ile geçiştirilmiştir. Özetle mağaranın derinlikleri, filmde yeteri kadar verilmediği için Mazhar Bey’in psikolojik dönüşümü ve adeta melek olması çok da mantıklı olarak dayandırılamamaktadır. Salt diyaloglar üzerinden verilmekte, Emine'nin çilesine giden yol gibi seyirciyi ikna eden bir haklılıkta verilmemektedir. $\mathrm{Bu}$ sebeple, filmin adı da olan bu yol ayrımı, filmlerde tırmanışı sağlayan çatışmayı seyirciye geçirememektedir. $\mathrm{Bu}$ anlamda oyunculuk ve diyaloglar iyi olmasına rağmen, yapısal anlamda görülen muğlaklık, filmin uluslar arası bağlamda başarılı olmasını güçleştireceği ön görülmektedir. 


\section{Kaynaklar}

Arıcı Sevinç, A. (2019). Eleştirel Yaklaşımla, Bilimkurgu Sineması ’nda Mitolojik Anlatımın Işslevi: Örnek Film Çözümlemesi: “Interstellar”. (Yayımlanmamış Yüksek Lisans Tezi). Marmara Üniversitesi Sosyal Bilimler Enstitüsü Radyo TV ve Sinema Anabilim Dalı Sinema Bilimdalı, İstanbul.

Bayat, F. (2007). Mitolojiye Giriş. İstanbul: Ötüken Yayınları

Bahtiyar, Y. (2016). Postmodern Bir Roman Yedinci Gün'de Mitin İşlevi ve Kahramanın Yolculuğu. (Yayımlanmamış yüksek lisans tezi). Yıldız Teknik Üniversitesi Sosyal Bilimler Enstitüsü Türk Dili ve Edebiyatı Anabilim Dalı, İstanbul.

Campbell, J. ve Moyers, B. (2021). Mitolojinin Gücü. İstanbul: MediaCat Yayınları.

Campbell, J. (2010). Kahramanın Sonsuz Yolculuğu. İstanbul: Kabalcı Yayınevi

Henderson, M. (1997). Star Wars: The Magic Of Myth. New York: Bantam Books.

Kasımoğlu, S. (2017). Binbir Gece Masallarında Kahraman İzlĕ̆i: Şehriyar'ın Farkındalık Yolculuğu. (Yayımlanmamış doktora tezi). Ankara Üniversitesi Sosyal Bilimler Enstitüsü Halkbilim Anabilim Dalı, Ankara.

Kırer, O. (2010). J.R.R. Tolkıen 'in Yüzüklerin Efendisi Romanının İlkörneksel Eleştiri Açısından Incelenmesi. (Yayımlanmamış yüksek lisans tezi). Erciyer Üniversitesi Sosyal Bilimler Enstitüsü İngiliz Dili ve Edebiyatı Anabilim Dalı, Erciyes.

Nurzhan, N. (2019). Kazak Türklerine Ait Boz Yiğit Destanı'nın Kahraman Monomiti Bă̆lamında Incelenmesi. (Yayımlanmamış Yüksek Lisans Tezi). Ardahan Üniversitesi Sosyal Bilimler Enstitüsü Türk Dili ve Edebiyatı Anabilim Dalı, Ardahan.

Ölçer, M. (2020). Kore Alfabesi Hangll İle Yazılmış İlk Roman Hong Gil-Dong Jeon Üzerine Bir Inceleme Joseph Campbell'ın Monomit Teorisi Bağlamında. (Yayımlanmamış yüksek lisans tezi). Erciyes Üniversitesi Sosyal Bilimler Enstitüsü Doğu Dilleri ve Edebiyatları Anabilim Dalı, Erciyes. 
Özmen, I. (2018). Monomit Şemasıyla Yapılandırılmış Animasyonlarda Kültür Aktarımı: Moana ve Spirited Away Örneği. (Yayımlanmamış Yüksek Lisans Tezi). İstanbul Arel Üniversitesi Sosyal Bilimler Enstitüsü, İstanbul.

Şentürk, E. (2017). Kahramanın Dönüşü Zemininde Bir Anlatı Çözümlemesi: Leyla ve Mecnun. (Yayımlanmamış yüksek lisans tezi). Gazi Üniversitesi Sosyal Bilimler Enstitüsü Türk Halk Bilimi Anabilim Dalı, Ankara.

Topaktaş, A. (2017). Adalet Ağaoğlu’nun Romanlarına Arketipsel Bir Yaklaşım. (Yayımlanmamış yüksek lisans tezi). Nevşehir Hacı Bektaş Veli Üniversitesi Sosyal Bilimler Enstitüsü Türk Dili ve Edebiyatı Anabilim Dalı, Nevşehir.

Tüysüz, D. (2019). Mitolojinin Sinemada Modern Yorumu: "Neredesin Be Birader?" ve "Kutsal Geyiğin Ölümü" Filmlerinde Çağdaş odysseus ve Agamemnon Hikâyeleri. Trakya Üniversitesi Sosyal Bilimler Dergisi. Cilt 21, 323-341.

Vogler, C. (2020). Yazarın Yolculuğu. İstanbul: Okyanus Yayınları. 